Jurnal Penyuluhan, September 2010 Vol. 6 No. 2

\title{
EVALUASI PROGRAM POS PEMBERDAYAAN KELUARGA (POSDAYA) (Studi Kasus Posdaya Bina Sejahtera di Kelurahan Pasirmulya, Kecamatan Bogor Barat, Kota Bogor, Jawa Barat)
}

\author{
Abdurrazzak Naufal dan Yatri Indah Kusumastuti \\ Departemen Sains Komunikasi dan Pengembangan Masyarakat, Fakultas Ekologi Manusia, \\ Institut Pertanian Bogor
}

\begin{abstract}
In respond to the government programs to alleviate the poverty and to improve the quality of the human resources of the remote communities, the family empowerment program was established. The establishment of such community development program is attempted to reach the target of the millenium development goals (MDGs), in its special interest for remote community development. The objectives of the study are: 1) to evaluate the progress of the Sejahtera Family Empowerment Program; 2) to investigate contraints and factors that support the development of the Empowerment Program; and 3) to analyse input, output, process and effects of the Posdaya Bina Sejahtera Program, on the community of Pasirmulya, Western Bogor District, West Java. Qualitative as well as the quantitative approach were utilized, in this study. Qualitative approach was used to get the deep understanding of the implementation of Family Empowerment Program, whereas the quantitative approach was used for the case study. Both the qualitative and quantitative approaches were sinergically utilized for more comprehensive result. For data collection, 50 questionaires were administered for community leaders, Bina Sejahtera officials, and community members purposively. This study brings together the current state of knowledge of how Posdaya has changed the quality of life of the community. From this study, it is suggested that Center for Human Resource Development (P2SDM) IPB, Yayasan Damandiri, as well as the Government should hands in hands to continue supporting the empowerment program.
\end{abstract}

Keywords : Evaluation, Empowerment, Posdaya

Abstrak

Menanggapi program pemerintah untuk mengurangi kemiskinan dan meningkatkan kualitas sumber daya manusia masyarakat terpencil, keluarga. Program pemberdayaan didirikan. Pembentukan komunitas tersebut Program pengembangan berusaha untuk mencapai target milenium tujuan pembangunan (MDGs), dalam perhatian khusus untuk masyarakat terpencil pengembangan. Tujuan dari penelitian ini adalah: 1) untuk mengevaluasi kemajuan Program Pemberdayaan Sejahtera Family; 2) untuk menyelidiki contraints dan faktor yang mendukung pengembangan dari Program Pemberdayaan; dan 3) untuk menganalisis input, output, proses dan efek dari Program Posdaya Bina Sejahtera, pada komunitas Pasirmulya, Kecamatan Bogor Barat, Jawa Barat. Kualitatif juga pendekatan kuantitatif digunakan, dalam penelitian ini. Pendekatan kualitatif adalah digunakan untuk mendapatkan pemahaman mendalam tentang pelaksanaan. Keluarga Program pemberdayaan, sedangkan pendekatan kuantitatif digunakan untuk kasus belajar. Kedua pendekatan kualitatif dan kuantitatif sinergis dimanfaatkan untuk hasil yang lebih komprehensif. Untuk pengumpulan data, 50 kuesioner yang diberikan untuk tokoh masyarakat, pejabat Bina Sejahtera, dan masyarakat anggota purposif. Penelitian ini menyatukan keadaan saat ini pengetahuan bagaimana Posdaya telah mengubah kualitas hidup masyarakat. Dari penelitian ini, Disarankan Pusat Pengembangan Sumber Daya Manusia (P2SDM) IPB, Yayasan Damandiri, serta Pemerintah harus tangan di tangan untuk melanjutkan mendukung program pemberdayaan.

Kata kunci: Evaluasi, Pemberdayaan, Posdaya

\section{Pendahuluan}

Peningkatan kualitas manusia sebagai sumberdaya pembangunan merupakan prasyarat utama untuk memperbaiki derajat kesejahteraan rakyat. Indonesia pada September tahun 2000 ikut menandatangani
Deklarasi Milenium pada Konfrensi Tingkat Tinggi (KTT) Perserikatan Bangsa-Bangsa (PBB). Deklarasi ini menyepakati tujuantujuan pembangunan global yang tertuang dalam tujuan pembangunan milenium (Millenium Development Goals - MDGs). Tujuan utama pembangunan milenium 
(Millenium Development Goals) di Indonesia memprioritaskan pada pengentasan kemiskinan. Menurut Data BPS November 2007 angka kemiskinan di Indonesia sebanyak 37,17 juta orang dan Human Development Index (HDI) Indonesia pada tahun 2008 adalah 0,726 yang berada di peringkat 109 dari 179 negara (UNDP, 2008).

Pemerintah telah menunjukkan komitmen untuk mencapai target yang ditetapkan dalam Millenium Development Goals (MDGs) 2015. Sejumlah kebijakan dan program nasional untuk pengentasan kemiskinan melalui pemberdayaan masyarakat, penguatan keluarga, pemerataan pendidikan dasar, jaminan sosial dan jaminan kesehatan, dan peningkatan kesehatan lingkungan telah diluncurkan. Keputusan itu merupakan tekad dan kebijaksanaan pemerintah yang perlu didukung semua instansi dan institusi pembangunan. Agar upaya itu berhasil dengan baik perlu diikuti dengan pengembangan gerakan pemberdayaan keluarga yang dilaksanakan secara intensif.

Pencapaian MDGs yang dibutuhkan kerjasama antara pemerintah sebagai pembuat kebijakan, swasta sebagai penggerak sektor perekonomian dan masyarakat sebagai pengkontrol dan pemberi aspirasi dampak pembangunan. Pemerintah pada tahun 2006 menyatakan bahwa pembangunan, utamanya pembangunan manusia dan keluarga, tidak saja menjadi tanggung jawab dan monopoli pemerintah, tetapi memerlukan kerja sama dan partisipasi masyarakat luas. Hal ini berkaitan dengan keterlibatan masyarakat dalam upaya pembangunan manusia yang secara tidak langsung akan berkontribusi dalam meningkatkan indeks pembangunan manusia (Human Development Index). Menurut Suyono dan Haryanto (2009) pilihan utama untuk meningkatkan MDGs dan HDI adalah program kesehatan, pendidikan dan ekonomi. Indikator pembangunan kesehatan adalah bertambahnya usia harapan hidup, indikator program pendidikan adalah tingkat partisipasi anak usia sekolah dan bebas buta aksara, cakupan semua anak usia sekolah, dan rata-rata lamanya anak bersekolah, sedangkan indikator program ekonomi adalah peningkatan tingkat pendapatan masyarakat.

Sebuah gagasan pemberdayaan masyarakat yang disebut dengan Pos Pemberdayaan Keluarga (Posdaya) muncul sebagai respon atas keinginan pemerintah dalam upaya untuk mengentaskan kemiskinan dan meningkatkan kualitas sumberdaya manusia (Suyono dan Haryanto, 2009). Upaya ini merupakan sumbangan dalam wujud nyata untuk mencapai target pembangunan abad millenium (MDGs) pada tingkat desa dan kelurahan. Pengembangan SDM dan Posdaya yang dilaksanakan tersebut dilakukan melalui kemitraan dengan sekolah SMA, Lembaga Swadaya Masyarakat, mitra kerja lain, dan Pemerintah Daerah.

Upaya dalam pengentasan kemiskinan melalui pemberdayaan dan peningkatan kualitas sumberdaya manusia, salah satu program pemberdayaan yang saat ini tengah dikembangkan oleh Pusat Pengembangan Sumberdaya Manusia (P2SDM) IPB bekerjasama dengan Yayasan Damandiri adalah membangun dan mengembangkan Pos Pemberdayaan Keluarga (Posdaya) di wilayah-wilayah yang memiliki kantong-kantong kemiskinan baik tingkat desa, dusun, atau RW. Menurut Suyono dan Haryanto (2009) Posdaya sebagai forum informasi, pendidikan dan pemberdayaan serta penyegaran partisipasi masyarakat secara mandiri. Sasaran akhir Posdaya adalah membentuk manusiamanusia yang bermutu dan sejahtera. Posdaya menggunakan keluarga sebagai ujung tombak untuk memperbaiki pendidikan, kesehatan dan ekonomi masyarakat dengan pilar keswadayaan dan kemandirian sebagai semangat kerjanya. Posdaya mewadahi kegiatan dari masyarakat, oleh masyarakat dan untuk masyarakat dengan inti kegiatan di bidang pendidikan, kesehatan dan ekonomi.

Menurut Suyono dan Haryanto (2009), Posdaya sebagai sebuah gagasan 
pemberdayaan dari, oleh, dan untuk masyarakat adalah sebuah kegiatan pemberdayaan masyarakat yang mengimplementasikan nilai-nilai kegotongroyongan di masyarakat. Posdaya adalah sebuah gerakan dengan ciri khas "bottom up programme", kemandirian, dan pemanfaatan sumberdaya serta potensi lokal sebagai sumber segala solusi. Pihak "luar" hanya berperan sebagai fasilitator, mediator dan pembangkit gagasan. Posdaya yang telah difasilitasi pembentukannya dan didampingi oleh P2SDM IPB bersama Yayasan Damandiri mulai tahun 2006 terdiri dari Posdaya di Kota Bogor, Kabupaten Bogor, Cianjur dan Sukabumi. Tujuan umum dari penelitian ini adalah untuk mengetahui perkembangan program Posdaya dan perubahan yang terjadi di masyarakat terutama di bidang pendidikan, kesehatan dan ekonomi.

\section{Metode Penelitian}

Pendekatan yang digunakan dalam penelitian ini adalah pendekatan kualitatif dengan didukung pendekatan kuantitatif. Pendekatan kualitatif dalam penelitian ini digunakan untuk menghasilkan data deskriptif berupa kata-kata lisan atau tulisan dari manusia atau tentang perilaku manusia yang dapat diamati (Taylor dan Bogdan, 1984 dalam Sitorus, 1998). Pendekatan kualitatif digunakan untuk mendapatkan pemahaman yang mendalam tentang program Posdaya.

Metode kualitatif yang digunakan adalah studi kasus, dengan metode ini dimungkinkan untuk diperoleh informasi secara mendalam, sehingga dapat menjelaskan peristiwa atau gejala sosial yang terjadi di masa sekarang, atau masih dalam rentang pengalaman/ingatan warga masyarakat yang dikaji. Menurut Yin (2002), menyatakan bahwa studi kasus lebih dikehendaki untuk melacak peristiwaperistiwa kontemporer (masa kini), bila peristiwa-peristiwa yang bersangkutan tidak dapat dimanipulasi. Strategi studi kasus digunakan karena mampu menggali pengalaman yang sudah terjadi, kemudian menarik tafsir yang bermakna pada tindakantindakan berbagai pihak dalam program pemberdayaan. Analisis juga bisa dilakukan terhadap data-data perkembangan wilayah dalam waktu yang berbeda, bersamaan dengan perencanaan maupun implementasi program.

Studi kasus juga dapat digunakan dalam merumuskan suatu peramalan perjalanan masyarakat pemanfaat. Pada kenyataannya ramalan studi wilayah kasus tahun-tahun sebelumnya ternyata teruji diterima dalam kedatangan (restudi) pada tahun-tahun berikutnya (Agusta, 2000). Strategi dalam metode kualitatif yang dipakai ialah studi kasus instrumental, baik yang diperoleh di lapangan maupun melalui literatur. Dalam strategi ini generalisasi diperoleh sejauh muncul dalam kasus-kasus itu sendiri (Stake, 1995). Perbandingan antar kasus dilakukan untuk menemukan tipe-tipe konteks masyarakat, yang dari sana diperoleh kaitannya dengan pola pelaksanaan program pemberdayaan. Evaluasi terhadap kaitan antara kinerja pelaksanaan program pemberdayaan dan konteks lokasi setempat berguna untuk memberi pengertian mendalam mengenai mengapa suatu pola pemikiran, sikap dan tindakan dilakukan oleh pihak-pihak terkait di atas. Konteks lokasi mencakup konteks fisik, ekonomi, dan demografi, konteks struktur. Dengan demikian penulis diharapkan dapat mengkaji dan memaparkan program secara objektif.

Pendekatan kuantitatif dilakukan menggunakan metode survai yaitu penelitian yang mengambil sampel dari suatu populasi dan menggunakan kuesioner sebagai alat pengumpul data yang pokok (Singarimbun dan Effendy, 1989). Pendekatan kuantitatif ini dilakukan secara sinergis dengan pendekatan kualitatif agar diperoleh data yang komprehensif tentang objek yang diteliti.

Responden dalam penelitian ini adalah para kader dan anggota program Posdaya yang aktif mengikuti kegiatan serta juga dari sebagian masyarakat yang dapat mewakili populasi. Jumlah responden 
ditentukan sebanyak 50 orang. Unit analisis yang dipilih dalam penelitian ini adalah individu.

\section{Posdaya Bina Sejahtera}

Proses pembentukan Posdaya dilatarbelakangi oleh adanya keinginan, kebutuhan, harapan dan tujuan yang sama memajukan warga masyarakat dalam berbagai bidang kegiatan untuk meningkatkan pengetahuan, sikap dan keterampilan agar mampu berusaha dan hidup mandiri dengan kemampuan sendiri, sehingga pada akhirnya dapat meningkatkan pendapatan keluarga dan hidup lebih sehat sejahtera. Namun kendala selalu datang terutama untuk menemukan pihak lain yang mampu memberikan dorongan motivasi, bimbingan dan program pendampingan yang jelas, teratur dan berkelanjutan.

Pada bulan Mei 2007, warga RW 02 terpilih menjadi salah satu calon kelurahan yang akan mendapatkan bimbingan dari Program Pos Pemberdayaan Keluarga (Posdaya). Pada tanggal 8 Mei 2007 diselenggarakan lokakarya Posdaya yang diprakarsai oleh P2SDM IPB dan Yayasan Damandiri, dihadiri oleh Kepala Kelurahan Pasirmulya, Ketua RW, Tokoh Masyarakat, Tokoh Agama, Kepala Lembaga Pendidikan dan warga masyarakat RW 02. Pada lokakarya tersebut menghasilkan dua kesepakatan antara lain :

1. Tersusun dan terbentuknya Tim Kerja

Posdaya Kelurahan Pasir Mulya.

2. Ditetapkan wilayah RW.02 sebagai contoh pelaksanaan Program Posdaya

di Kelurahan Pasir Mulya.

Pada tanggal 21 Mei 2007 telah dikukuhkan Tim Kerja Posdaya Pasirmulya melalui Surat Keputusan yang dibuat oleh Kepala Kelurahan Pasirmulya No. 147/08PM. Tentang Pembentukan Posdaya Kelurahan Pasirmulya dan ditetapkan bahwa dengan keluarnya Surat Keputusan tersebut menjadi tanggal terbentuknya Posdaya di Kelurahan Pasir Mulya. Menindaklanjuti dari pengukuhan tersebut maka pada tanggal 1 Maret 2008 yang diprakarsai Ketua RW 02 diselenggarakan rapat khusus pembentukan Kelompok Kerja untuk melaksanakan beberapa Program Kerja. Berdasarkan hasil kesepakatan warga masyarakat yang hadir pada waktu itu, maka secara aklamasi dan disepakati nama Posdaya adalah Bina Sejahtera. Posdaya " Bina Sejahtera “ beralamat di Bojong Menteng RT 02 / RW 02 Kelurahan Pasir Mulya Kecamatan Bogor Barat Kota Bogor Provinsi Jawa Barat. Lokasi ini berada di bagian Barat Kota Bogor, berbatasan dengan Kecamatan Ciomas Kabupaten Bogor. Jarak dari ibukota Kota Bogor sekitar $\pm 1 \mathrm{~km}$.

Proses pembentukan Posdaya Bina Sejahtera dapat disimpulkan dilakukan melalui empat tahapan yakni membangun kemitraan, identifikasi potensi secara partisipatif, lokakarya penetpan program dan menetapkan bentuk dan kegiatan yang akan dilakukan kedepannya. Sebelum adanya Posdaya mereka tidak mempunyai kegiatan pemberdayaan atau semacamnya yang mempunyai arah kegiatan yang jelas.

\section{Evaluasi Program POSDAYA}

Program yang sedang berlangsung maupun yang telah selesai dilaksanakan perlu dievaluasi untuk mengetahui apakah program yang dilaksanakan sudah tepat. Oleh karena itu, perlu dievaluasi mulai dari input, pelaksanaan, output, efek dan dampak dari suatu program Posdaya. Kegiatan Posdaya agar berhasil dan berdaya guna sesuai dengan tujuan dan sasaran yang telah digariskan, perlu diadakan pemantauan oleh pihak P2SDM IPB dan Yayasan Damandiri terhadap kegiatan yang telah dan sedang dilaksanakan. Kegiatan pemantauan tersebut mempunyai tujuan untuk melakukan kontrol agar program Posdaya terus berjalan agar sesuai dengan tujuan dan sasaran yang telah ditetapkan, membantu menyelesaikan masalah yang dihadapi, dan memantau realisasi dari penggunaan dana dan sarana. 


\section{Input Program}

\begin{abstract}
Evaluasi input dilakukan mengenai hal-hal yang perlu tersedia dalam pelaksanaan suatu program. Dalam hal ini input yang dikaji berupa tujuan program, sasaran program, sumberdaya manusia (SDM), dan anggaran/biaya.
\end{abstract}

\section{Tujuan Program}

Program Posdaya Bina Sejahtera yang telah berlangsung mempunyai beberapa tujuan, yaitu :

1. Membangkitkan budaya sosial kemasyarakatan yang bergotongroyong dan peduli kepada sesama.

2. Mengembangkan kelembagaan dalam masyarakat yang memiliki usaha bersama sehingga tercipta kerukunan dan dinamika yang serasi menuju taraf hidup sejahtera.

3. Membentuk wadah organisasi dan wahana partisipasi sosial untuk menerima pembaharuan dalam membangun kehidupan keluarga yang aman, tenteram dan bahagia.

Ketiga tujuan di atas merupakan tujuan yang dinilai baik oleh pengurus dan kader. Mereka pun siap dalam melaksanakan kegiatan di bidang pendidikan, kesehatan dan ekonomi dengan harapan dapat mencapai tujuan akhir program Posdaya tersebut.

\section{Sasaran Program}

Sasaran program Posdaya adalah terselenggaranya upaya bersama agar setiap keluarga mempunyai kemampuan melaksanakan delapan fungsi keluarga. Dalam rangka pelaksanaan MDGs, pengembangan fungsi keluarga tersebut diarahkan kepada lima prioritas sasaran utama, yaitu komitmen para pimpinan dan sesepuh tingkat desa dan pedukuhan, kecamatan dan kabupaten, pengembangan fungsi keagamaan, fungsi $\mathrm{KB}$ dan kesehatan, fungsi pendidikan, fungsi kewirausahaan dan fungsi lingkungan hidup yang memberi makna terhadap kehidupan keluarga yang bahagia dan sejahtera.

Dengan demikian melalui upaya bersama tersebut akan menjadikan Posdaya sebagai wahana untuk membantu pemberdayaan keluarga yang memungkinkan setiap keluarga bisa saling belajar dari keluarga lain, atau dari narasumber yang didatangkan secara khusus ke Posdaya. Melalui pemberdayaan tersebut diharapkan setiap keluarga mampu menjadi subyek yang secara mandiri membangun seluruh anggota keluarganya.

Secara bertahap untuk mencapai sasaran pemberdayaan keluarga melalui Posdaya dapat ditempuh melalui langkahlangkah dengan materi muatan sebagai berikut :

1. Peningkatan kepedulian dan komitmen pemimpin atau sesepuh masyarakat pada umumnya

2. Pemberdayaan fungsi keagamaan dan budi pekerti

3. Pemberdayaan fungsi KB dan kesehatan

4. Pemberdayaan fungsi pendidikan

5. Pemberdayaan fungsi kewirausahaan

6. Pemberdayaan lingkungan hidup dan keluarga bergizi

\section{Sumber Daya Manusia (SDM)}

Sumber daya manusia (SDM) adalah potensi yang terkandung dalam diri manusia untuk mewujudkan perannya sebagai makhluk sosial yang adaptif dan transformatif yang mampu mengelola dirinya sendiri serta seluruh potensi yang terkandung di alam menuju tercapainya kesejahteraan kehidupan dalam tatanan yang seimbang dan berkelanjutan. Posdaya muncul sebagai respon atas keinginan pemerintah dalam upaya meningkatkan kualitas sumber daya manusia (Suyono dan Haryanto, 2009). Oleh karena itu, perlu dikaji mengenai SDM yang ada di RW 02 Pasir Mulya dan kemudian dilakukan wawancara mendalam mengenai kinerja SDM Posdaya Bina Sejahtera kepada pendamping dari P2SDM IPB. Ibu MT (41 tahun) salah satu pendamping Posdaya Bina Sejahtera mengatakan: 


"SDM Posdaya Bina Sejahtera
cukup memadai dan siap untuk
melaksanakan program Posdaya,
itulah salah satu faktor yang
membuat Posdaya disini cepat
berkembang dan mempunyai kinerja
yang baik."

Sebagian dari warga memiliki latar belakang pendidikan yang mencukupi dan sesuai dengan yang dibutuhkan dalam kepengurusan Posdaya. Pengurus dan kader Posdaya memilki komitmen untuk bersamasama mengembangkan Posdaya sampai mandiri. Hal ini merupakan modal postif dalam pelakanaan Posdaya. Pernah dilakukan evaluasi SDM pelaksana Posdaya di Bogor dan terlihat bahwa SDM Posdaya Bina Sejahtera lebih unggul dari SDM Posdaya lainnya di Bogor.

\section{Anggaran / Biaya Posdaya}

Menurut Yayasan Damandiri, anggaran untuk membiayai kegiatan Posdaya berasal dari sumber-sumber berikut:

a. APBN : Dinas Kesehatan, Dinas Pendidikan, Dinas Sosial, Dinas Agama, Dinas Koperasi dan sektor pembangunan lain yang terkait

b. APBD : Pemerintah Propinsi, Pemerintah Kota dan Pemerinatah Kabupaten

c. Swadaya masyarakat dan sumbangan donatur lainnya

d. Perusahaan swasta sebagai tanggung jawab sosial.

Pada Posdaya Bina Sejahtera untuk membiayai kegaiatannya mereka hanya bertumpu pada dana swadaya masyarakat. Menurut pengakuan beberapa pengurus Posdaya mereka belum ada bantuan dari Pemerintah Kota mapun Dinas terkait. Jika ada bantuan pun hanya dari Yayasan Damandiri dan jumlahnya pun tidak terlalu besar sehingga belum terlalu membantu mereka. Pada awal pembentukan Posdaya diberikan dana sebesar Rp 2.500.000,- untuk modal pembiayaan kegiatan Posdaya Bina Sejahtera dan untuk selanjutnya dana kegiatan didapatkan dari swadaya pengurus, kader maupun masyarakat. Minimnya dana yang ada tentunya dapat mengahambat pelaksanaan dan keberlangsungan program Posdaya Bina Sejahtera. Dengan kondisi tersebut, tidak mematahkan semangat para pengrus dan kader. Pada wawancara mendalam yang dilakukan terhadap salah satu pengurus, Bapak EW (38 tahun) mengatakan:

\section{"Kami bener-bener mandiri} dek, pernah ada yang bantuan tapi hanya untuk operasional kegiatan saja, Untuk usaha kami kekeurangan modal untuk mengembangkan usaha, terus PAUD gurunya tidak dibayar. Bayarnya seikhlasnya aja, kan kasian dek,tapi ga mengurangi kinerjadan semangat para pengurus dan kader, semuanya ingin maju."

Kondisi yang serba seadanya tidak mengurangi tekad kuat dan komitmen pengurus dan kader Posdaya dalam mengembangkan Posdaya Bina Sejatera agar dapat mandiri dan memberdayakan masyarakat. Langkah ke depannya Posdaya Bina Sejahtera mengirimkan proposal kepada Pemerintah Kota Bogor untuk membantu pendanaan kegiatan Posdaya Bina Sejahtera dengan bantuan dana APBD.

\section{Pelaksanaan Tujuan Program dan Sasaran Program Posdaya}

Dalam pelaksanaan program Posdaya dari mulai penetapan tujuan dan sasaran program sampai dengan sosialisasi program dan partisipasi masyarakat dalam program Posdaya Bina Sejahtera berjalan sesuai dengan apa yang direncanakan. Pelaksanaan program tentunya disesuaikan dengan tujuan program yang telah dibuat. Hal itu tidak terlepas dari kemauan kuat dan keseriusan pengurus dan kader dalam pelaksanaan pada tahap tersebut. Pihak Kelurahan Pasir Mulya berperan besar dalam pembentukan awal Posdaya dan ikut mendukung melakukan 
sosialisasi kepada warga mengenai program Posdaya.

\section{Sosialisasi Program Posdaya}

Sosialisasi adalah tahap awal yang dilakukan oleh P2SDM IPB, Yayasan Damandiri dan dibantu oleh pihak Kelurahan Pasir Mulya agar program Posdaya dapat diterima dengan baik oleh masyarakat RW 02. Bentuk sosialisasi Posdaya dilakukan secara bertahap, yaitu perkenalan kepada pihak Kelurahan Pasir Mulya, tokoh masyarakat, tokoh agama dan tokoh wanita. Sosialisasi yang dilaksanakan kepada pihak Kelurahan Pasir Mulya berupa perkenalan diri pendamping dari P2SDM IPB dan program yang akan dibawa. Setelah pihak Kelurahan memahami banyaknya manfaat Posdaya kemudian pihak Kelurahan menyetujui program Posdaya diterapkan di RW 02.

Pada umumnya sosialisasi yang dilakukan untuk mencari kader Posdaya adalah dengan mendatangi rumah-rumah yang diduga dapat menjadi kader Posdaya. Metode ini dirasakan cukup efektif karena dapat bertemu langsung dengan warga sambil melihat kondisi keluarganya, keadaan usahanya atau menanyakan masalah dan menjadi kebutuhan yang benar-benar dibutuhkan oleh warga RW 02. Selain sosialisasi tersebut, juga dialkuakan sosialisasi melalui kegiatan warga seperti pengajian, arisan dan kerja bakti membersihkan lingkungan serta aktivitas keseharian warga seperti mendatangi ibu-ibu yang sedang berbelanja, membantu membuat kue dan makanan ringan. Pada dasarnya sosialisasi yang dilakukan di RW 02 Pasir Mulya adalah dengan mengikuti kebiasaankebiasaan yang ada pada masyarakat. Hal ini dimaksudkan agar tujuan dari program Posdaya Bina Sejahtera tercapai. Di samping itu, tujuan dari sosialisasi ini pada umumnya yaitu :

1. Untuk memperkenalkan program Posdaya Bina Sejahtera dan pendamping dari P2SDM IPB
2. Memberi motivasi kepada masyarakat untuk dapat ikutserta dalam program Posdaya.

\section{Partisipasi Masyarakat}

Partisipasi merupakan keterlibatan seseorang secara aktif dalam mengikuti suatu kegiatan di semua bidang yakni pendidikan, kesehatan dan ekonomi. Menurut Angell dalam Murray dan Lappin (1967) menyatakan bahwa faktor-faktor yang mempengaruhi partisipasi seseorang dalam mengikuti kegiatan di lingkungannya antara lain: (1) umur, (2) pekerjaan, (3) penghasilan, (4) pendidikan, dan (5) lama tinggal. Bentuk partisipasi warga RW 02 adalah dalam kegiatan Posdaya Bina Sejahtera mulai dari tahap perencanaan sampai dengan proses evaluasi itu sendiri. Indikator partisipasi masyarakat terhadap program Posdaya Bina Sejahtera meliputi sikap dan peranannya dalam tahap partisipasi menurut Cohen dan Uphoff (1977) dalam Febriana (2008) yaitu pengambilan keputusan/perencanaan, pelaksanaan, menikmati hasil dan evaluasi kegiatan.

\section{a. Partisipasi Tahap Perencanaan}

$\begin{array}{ccc}\text { Partisipasi } & \begin{array}{c}\text { warga pada } \\ \text { dinyatakan }\end{array} & \text { tahap } \\ \text { perencanaanai }\end{array}$ keikutsertaan responden dalam mengikuti rapat penyusunan rencana suatu kegiatan. Pada tahap perencanaan yang dinilai adalah kehadiran responden dalam rapat perencanaan program dan keaktifan dalam rapat tersebut. Hasil penelitian menunjukkan bahwa 56 persen responden memiliki partisipasi yang tinggi pada tahap perencanaan dan 44 persen responden memilki partisipasi yang rendah. Menurut para responden memang tidak ada keharusan untuk menghadiri rapat perencanaan program Posdaya Bina Sejahtera yang biasanya dilakukan di sekretariat Posdaya. Biasanya dalam rapat perencanaan tersebut hanya dihadiri oleh kader dan pengurus inti saja yang berjumlah sekitar 30 orang. Berdasarkan hasil wawancara dengan 
beberapa responden yang biasa hadir dalam rapat perencanaan, mereka mengakui bahwa mereka diberi kesempatan untuk bertanya dan memberikan saran atau pendapat. Bahkan tidak jarang pendapat atau usul mereka diterima sebagai bahan masukan.

Responden sebanyak 62 persen yang memiliki tingkat partisipasi tinggi pada tahap perencanaan adalah pengurus atau kader yang hadir dalam rapat perencanaan program lebih dari dua kali dan dalam rapat tersebut mereka tidak hanya hadir tetapi juga bertanya dan memberikan usulan atau pendapat. Namun ketika tahap pengambilan keputusan tidak semua kader dilibatkan, hanya pengurus saja yang dapat mengambil keputusan. Tingkat partisipasi masyarakat dalam tahap perencanaan dapat dilihat pada Tabel 1.

Tabel 1. Tingkat Partisipasi RW 02 Kelurahan Pasir Mulya Dalam Tahap Perencanaan Program Posdaya Bina Sejahtera Tahun 2009

\begin{tabular}{|l|c|c|}
\hline \multicolumn{1}{|c|}{ Tahap Perencanaan } & Jumlah (orang) & Persentase (\%) \\
\hline Rendah & 22 & 44 \\
\hline Tinggi & 28 & 56 \\
\hline Total & 50 & 100 \\
\hline
\end{tabular}

\section{b. Partisipasi Tahap Pelaksanaan}

Partisipasi warga pada tahap pelaksanaan dinyatakan dalam keikutsertaan dan keaktifan warga pada pelaksanaan kegiatan Posdaya. Partisipasi pada tahap pelaksanaan diukur berdasarkan banyaknya kegiatan yang diikuti oleh responden pada kegitan Posdaya Bina Sejahtera serta kehadiran/keaktifan dalam tiap-tiap kegiatan tersebut.

Partisipasi responden pada tahap pelaksanaan program Posdaya Bina Sejahtera tergolong tinggi yakni 84 persen, sedangkan 16 persen responden memiliki partisipasi yang rendah. Para responden yang memiliki partisipasi tinggi biasanya terlibat dalam berbagai kegiatan Posdaya Bina Sejahtera baik di bidang pendidikan, kesehatan dan ekonomi seperti PAUD, BKB, posyandu balita dan posbindu lansia, LKM-P, usahatani ramah lingkungan dan kegiatan lainnya. Namun, berdasarkan penelitian di lapangan program Pustaka Keliling mengalami penurunan partisipasi, karena buku yang dipinjamkan belum bertambah dan kurang bervariasi sehingga warga pun cenderung bosan. Sementara kegiatan yang paling sering diikuti adalah di bidang kesehatan yakni BKB, Posyandu balita dan lansia, hal ini dikarenakan Posyandu ditujukan dai mulai anak-anak sampai dewasa pun bisa ikut berpartisipasi dan mereka tertarik dengan adanya pengobatan dan pemeriksaan kesehatan secara gratis.

Responden yang memiliki partisipasi rendah hanya terlibat pada beberapa program atau bahkan tidak pernah mengikuti kegiatan Posdaya Bina Sejahtera. Mereka juga beralasan tidak memiliki waktu untuk berpartisipasi dan ada sebagian responden yang pesimis dan tidak peduli dengan program Posdaya Bina Sejahtera. Hal tersebut merupakan sesuatu yang wajar dikarenakan suatu program pasti tidak selalu ditanggapi positif, tetapi juga ada yang menilai negatif dan berdasarkan data yang diperoleh hanya 8 orang responden yang berpartisipasi rendah. Tingkat partisipasi masyarakat dalam tahap pelaksanaan dapat dilihat pada Tabel 2.

Tabel 2. Tingkat Partisipasi RW 02 Kelurahan Pasir Mulya Dalam Tahap Pelaksanaan Program Posdaya Bina Sejahtera Tahun 2009

\begin{tabular}{|l|c|c|}
\hline \multicolumn{1}{|c|}{ Tahap Pelaksanaan } & Jumlah (orang) & Persentase (\%) \\
\hline Rendah & 8 & 16 \\
\hline Tinggi & 42 & 84 \\
\hline Total & 50 & 100 \\
\hline
\end{tabular}




\section{c. Partisipasi Tahap Menikmati Hasil}

Partisipasi warga dalam tahap menikmati hasil yaitu keikutsertaan responden dalam merasakan manfaat dari program Posdaya. Partisipasi pada tahap menikmati hasil diukur dari manfaat/keterampilan yang didapat oleh responden dari kegiatan Posdaya Bina Sejahtera serta bagaimana dia menerapkan keterampilan tersebut dalam kehidupan sehari-hari.

Responden yang memiliki partisipasi tinggi pada tahap menikmati hasil sebanyak 82 persen, sedangkan yang memiliki partisipasi rendah sebanyak 18 persen. Sebagian besar responden mengaku setelah adanya program Posdaya Bina Sejahtera, khususnya program kesehatan, dalam kegiatan BKB mereka mendapatkan banyak pengetahuan mulai dari penyuluhan $\mathrm{KB}$, kemudian pentingnya menjaga kebersihan lingkungan dan menerapkan menu gizi yang seimbang.

Selain itu melalui posyandu balita dan posbindu lansia, mereka dapat memeriksakan kondisi kesehatannya dengan biaya yang murah bahkan ada yang diberikan pengobatan secara cuma-cuma atau gratis, sehingga warga yang tidak mampu dapat mengakses pelayanan kesehatan juga, tidak lagi terbentur masalah biaya. Menurut Ibu PH (23 tahun) mengatakan :

\section{"Wah, kita mah seneng banget dek klo ada Posyandu sama BKB, lumayan bisa ngecek gratis ga perlu ke dokter, lagian obatnya juga lumayan cocok."}

Responden yang mengikutsertakan anaknya dalam kegiatan PAUD juga mengaku merasa tebantu dengan adanya PAUD karena anak-anaknya mendapatkan pengetahuan dan dapat bersosialisasi dengan anak-anak seumurannya.

Secara keseluruhan program Posdaya memberikan manfaat tidak hanya bagi responden yang mengikuti program Posdaya Bina Sejahtera, masyarakat yang diluar program Posdaya pun ikut merasakan manfaatnya. Tingkat partisipasi masyarakat dalam tahap menikmati hasil dapat dilihat pada Tabel 3 .

Tabel 3. Tingkat Partisipasi RW 02 Kelurahan Pasir Mulya Dalam Tahap Menikmati Hasil Program Posdaya Bina Sejahtera Tahun 2009

\begin{tabular}{|l|c|c|}
\hline \multicolumn{1}{|c|}{ Tahap Menikmati Hasil } & Jumlah (orang) & Persentase (\%) \\
\hline Rendah & 9 & 10 \\
\hline Tinggi & 41 & 90 \\
\hline Total & 50 & 100 \\
\hline
\end{tabular}

\section{d. Partisipasi Tahap Evaluasi}

Partisipasi warga pada tahap evaluasi yaitu keikutsertaan responden dalam mengevaluasi kegiatan-kegiatan yang dilaksanakan oleh Posdaya. Partisipasi warga dikukur melalui keikutsertaan mereka dalam rapat evaluasi triwulan dan perean mereka dalam membuat laporan baik lisan maupun tulisan berkaitan dengan program Posdaya yang dilakukan. Rapat evaluasi biasanya hanya dihadiri oleh kader dan pengurus inti saja, namun terkadang anggota, tokoh masyarakat dan warga yang pengurus Posdaya juga sering diundang hadir dalam rapat

tersebut untuk dimintai pendapat dan saran terhadap pelaksanaan Posdaya Bina Sejahtera.

Menurut Bapak AH (45 tahun) ketua Posdaya Bina Sejahtera mengatakan :

"Rapat evaluasi triwulan sangat bermanfaat, selain untuk mengukur dan mengevaluasi kegiatan yang dilakukan juga 
bermanfaat melatih warga untuk berani berbicara di depan umum dan berlatih berorganisasi yang baik."

Secara keseluruhan, partisipasi warga dalam tahap evaluasi tergolong tinggi yakni sebanyak 68 persen. Mereka antusias apabila ada rapat triwulan, yang dapat dijadikan sebagai ajang silaturahmi dan berkumpul. Para kader biasanya melaporkan kepada ketua Posdaya apa saja yang telah mereka lakukan selama tiga bulan terakhir. Tingkat partisipasi masyarakat dalam tahap evaluasi dapat dilihat pada Tabel 4.

Tabel 4. Tingkat Partisipasi RW 02 Kelurahan Pasir Mulya Dalam Tahap Evaluasi Program Posdaya Bina Sejahtera Tahun 2009

\begin{tabular}{|l|c|c|}
\hline \multicolumn{1}{|c|}{ Tahap Evaluasi } & Jumlah (orang) & Persentase (\%) \\
\hline Rendah & 16 & 32 \\
\hline Tinggi & 34 & 68 \\
\hline Total & 50 & 100 \\
\hline
\end{tabular}

e. Partisipasi Masyarakat Dalam Program Posdaya Bina Secara Keseluruhan

Tingkat partisipasi masyarakat diukur dengan cara menjumlahkan skor total pada tahap-tahap partisipasi yang diperoleh pada masing-masing responden. Secara umum, tingkat partisipasi masyarakat dalam kegiatan Posdaya Bina Sejahtera tergolong tinggi. Masyarakat cukup antusias mengikuti kegiatan yang dilaksanakan. Dari total responden sebanyak 50 orang, didapat 45 orang (90 persen) yang selalu berpartispasi dalam kegiatan Posdaya atau partisipasi tinggi, sedangkan 5 orang lainnya (10 persen) memiliki partisipasi yang rendah. Tingkat partisipasi masyarakat dapat dilihat pada Tabel 5.

Tabel 5. Tingkat Partisipasi RW 02 Kelurahan Pasir Mulya Secara Keseluruhan Dalam Program Posdaya Bina Sejahtera Tahun 2009

\begin{tabular}{|l|c|c|}
\hline \multicolumn{1}{|c|}{ Tahap Partisipasi } & Jumlah (orang) & Persentase (\%) \\
\hline Rendah & 5 & 10 \\
\hline Tinggi & 45 & 90 \\
\hline Total & 50 & 100 \\
\hline
\end{tabular}

Responden yang memiliki partisipasi tinggi adalah responden yang total skornya lebih dari atau sama dengan 19, sedangkan responden yang memilki tingkat partisipasi rendah adalah responden dengan total skor kurang dari 19. Secara keseluruhan tingkat partisipasi warga RW 02 yang tergolong tinggi dikarenakan warga dapat berpartisipasi aktif, mereka menyambut positif dan antusias terhadap program Posdaya di semua bidang yakni pendidikan, kesehatan dan ekonomi. Proses sosialisasi program berjalan dengan baik sehingga program dapat diterima dengan baik, dan warga pun merasakan manfaat program Posdaya. Keterbatasan waktu tidak menjadi masalah karena pengurus dan kader mepunyai komitmen yang kuat untuk mengembangkan Posdaya sehingga mereka dapat mengelola waktu untuk bekerja dan waktu untuk kegitan Posdaya secara baik. Dalam kepengurusan Posdaya pun tidak ada yang rangkap jabatan, mereka hanya diberikan satu beban tugas agar fokus dalam melaksanakan tugasnya. Cara tersebut dinilai berhasil karena setiap pengurus tidak merasa terbebani dan optimal dalam melaksanakan tugasnya masing-masing.

Warga yang berpartisipasi rendah sebanyak 10 persen responden disebabkan karena mereka disibukan dengan pekerjaan dari tempat mereka bekerja, sehingga tidak bisa berpartisipasi aktif terhadap program Posdaya, namun mereka menyambut baik 
dan merasa senang dengan kegiatan Posdaya. Mereka pun ikut mendukung program tersebut, walaupun tidak terlibat secara langsung, sedangkan sebanyak 90 persen responden yang berpartisipasi tinggi adalah warga yang aktif dalam berbagai kegiatan Posdaya Bina Sejahtera mulai dari tahap perencanaan, pelaksanaan, menikmati hasil hingga evaluasi. Pada tahap perencanaan, mereka hadir dalam rapat perencanaan lebih dari dua kali dan pada rapat tersebut mereka bertanya ataupun memberikan usul/pendapat. Pada tahap pelaksanaan, mereka aktif dalam berbagai program Posdaya Bina Sejahtera yang dilakukan baik di bidang pendidikan, kesehatan dan ekonomi seperti PAUD, Pustaka Keliling, BKB, posyandu balita dan posbindu lansia, LKM-P, usaha tani ramah lingkungan dan kegiatan lainnya. Pada tahap menikmati hasil, mereka mendapatkan keterampilan dari program yang diikuti dan menerapkannya dalam kehidupan sehari-hari. Tahap yang terakhir yakni tahap evaluasi warga pun berpartisipasi secara aktif walaupun yang melakukan rapat evaluasi hanya diwakilkan pengurus dan kader inti Posdaya Bina Sejahtera. Dalam rapat evaluasi yang dilakukan tiap tiga bulan sekali kader dan penanggung jawab kegiatan melaporkan hasil yang telah mereka lakukan selama ini kepada ketua Posdaya. Mereka pun aktif dalam rapat evaluasi tersebut dengan memberikan saran terhadap pelaksanaan program dan terlihat antusias apabila ada rapat triwulan, yang dapat dijadikan sebagai ajang silaturahmi dan berkumpul.

\section{Output Program}

Output program adalah suatu hal yang diharapkan terjadi atau dihasilkan setelah input tersedia dan proses dilaksanakan sampai selesai. Output yang diterima oleh warga RW 02 tampak pada perubahan pengetahuan, perubahan sikap dan perubahan perilaku masyarakat. Sebagian besar warga RW 02 merasakan adanya perbedaan sebelum dan sesudah adanya Posdaya. Dari 50 orang responden yang ditanyakan mengenai hal ini 36 orang setuju jika ada terdapat perubahan sebelum dan sesudah adanya Posdaya dan 14 orang tidak setuju terdapat perubahan sebelum dan sesudah adanya Posdaya.

\section{a. Perubahan Pengetahuan}

Program Posdaya membawa perubahan bagi warga RW 02. Perubahan pengetahuan salah satu dari perubahan tersebut. Perubahan pengetahuan adalah pengetahuan tentang program Posdaya dimana masyarakat yang tadinya tidak mengetahui program Posdaya menjadi mengetahui Program Posdaya dan dapat mengambil manfaat positifnya, seperti bertambahnya pengetahuan mereka.

Responden yang menjawab adanya perubahan pengetahuan setelah adanya Posdaya sebanyak 84 persen, sedangkan responden yang menjawab tidak adanya perubahan setelah adanya Posdaya sebanyak 16 persen. Sebanyak 42 orang yang menjawab adanya perubahan pengetahuan mengatakan setelah mengetahui adanya Posdaya dan kemudian mengikuti kegiatannya mendapatkan pengetahuan tentang Keluarga Berencana (KB), pengetahuan tentang menerapkan menu gizi yang seimbang, pengetahuan tentang usaha tani dan pengetahuan tentang cara mendidik anak-anak, sedangkan 8 orang yang menjawab tidak adanya perubahan setelah adanya Posdaya biasanya responden yang tidak terlalu aktif dalam lingkungannya dan tidak mempunyai waktu luang untuk mengikuti Posdaya sehingga mereka tidak merasakan perubahan setelah adanya Posdaya. Hal ini dapat dilihat pada Tabel 6. 
Tabel 6. Perubahan Pengetahuan Warga RW 02 Kelurahan Pasir Mulya Terhadap Program Posdaya Bina Sejahtera Tahun 2009

\begin{tabular}{|l|c|c|}
\hline \multicolumn{1}{|c|}{ Perubahan Pengetahuan } & Jumlah (orang) & Persentase (\%) \\
\hline Rendah & 42 & 84 \\
\hline Tinggi & 8 & 16 \\
\hline Total & 50 & 100 \\
\hline
\end{tabular}

\section{c. Perubahan Sikap}

Perubahan sikap adalah respon terhadap pengetahuan yang diterima tentang program Posdaya kemudian bersikap menyukai dan menyetujui program Posdaya atau tidak menyukai dan menyetujui program
Posdaya. Responden yang merespon positif atau menyukai dan menyetujui program Posdaya sebanyak 88 persen, sedangkan responden yang merespon negatif atau tidak menyukai dan menyetujui program sebanyak 12 persen. Hal ini disajikan dalam Tabel 7.

Tabel 7. Perubahan Sikap Warga RW 02 Kelurahan Pasir Mulya Terhadap Program Posdaya Bina Sejahtera Tahun 2009

\begin{tabular}{|l|c|c|}
\hline \multicolumn{1}{|c|}{ Perubahan Sikap } & Jumlah (orang) & Persentase (\%) \\
\hline Positif & 44 & 88 \\
\hline Negatif & 6 & 12 \\
\hline Total & 50 & 100 \\
\hline
\end{tabular}

\section{c. Perubahan Perilaku}

Perubahan perilaku adalah tindakan yang dilakukan sebagai respon terhadap program Posdaya dimana masyarakat aktif atau pasif berpartisipasi dan ikutserta dalam program Posdaya Bina Sejahtera. Dalam Tabel 8 terlihat sebanyak 90 persen responden yang mengaku aktif atau sering berpartisipasi dalam kegiatan Posdaya Bina Sejahtera, sedangkan 10 persen responden yang mengaku pasif atau jarang bahkan tidak pernah berpartisipasi dalam kegiatan Posdaya Bina Sejahtera. Sebagian besar responden yang aktif ikutserta dalam kegiatan Posdaya merasakan manfaat dari mengikuti kegiatan tersebut diantaranya yakni sebagai latihan dalam berorganisasi, berlatih berbicara di depan umum, dan manfaat lainnya.

Tabel 8. Perubahan Perilaku Warga RW 02 Kelurahan Pasir Mulya Terhadap Program Posdaya Bina Sejahtera Tahun 2009

\begin{tabular}{|l|c|c|}
\hline Perubahan Perilaku & Jumlah (orang) & Persentase (\%) \\
\hline Aktif & 45 & 90 \\
\hline Pasif & 5 & 10 \\
\hline Total & 50 & 100 \\
\hline
\end{tabular}

\section{Efek Program}

Efek adalah hasil dari pelaksanaan program (Kunarjo, 2002). Efek program dari pelaksanaan program Bina Sejahtera dilihat dari 3 bidang yang difokuskan yakni pendidikan, kesehatan dan ekonomi.

\section{a. Pendidikan}

Efek dari program Posdaya di bidang pendidikan adalah adanya kemudahan akses dan peningkatan pengetahuan. Dengan adanya program PAUD dan pustaka keliling warga RW 02 kini memiliki program pendidikan untuk meningkatkan pengetahuan mereka. Sasaran program PAUD adalah 
anak-anak karena diharapkan apabila sejak dini mereka dibekali pengetahuan dan minat baca yang tinggi, maka akan muncul generasi anak-anak yang cerdas dan potensial di masa depan.

Warga yang memiliki balita berusia 2-5 tahun banyak yang mengikutsertakan putra-putri mereka dalam PAUD. Anak-anak yang mengikuti kegiatan tersebut pun tampak senang dan ceria dalam mengikuti kegiatan tersebut. Jumlah anak yang mengikuti setiap tahunnya terus bertambah. Pada tahun 2008 saat awal pembentukan Posdaya, jumlah murid-murid PAUD Bina Mentari berjumlah 28 anak dan kini pada tahun 2009 jumlah muridnya mencapai 45 anak. Para murid pun tidak hanya berasal dari RW 02 saja, warga dari daerah sekitar RW 02 pun tertarik mengikutsertakan anakanak mereka dalam PAUD Bina Mentari. Peningkatan partisipasi dalam PAUD tidak diikuti dengan Kegiatan Pustaka Keliling yang jumlahnya terus menurun. Hal tersebut dikarenakan buku-buku yang dipinjamkan tidak bertambah dan kurang variatif, sehingga anak-anak pun cenderung bosan dan menurun minat bacanya.

\section{b. Kesehatan}

Efek dari program Posdaya di bidang pendidikan adalah adanya peningkatan tingkat kesehatan masyarakat setelah adanya program di bidang kesehatan yakni posyandu balita, posbindu lansia dan BKB. Dalam kegiatan kesehatan juga terlihat mengalami kemajuan dan berdampak positif bagi warga masyarakat yakni BKB dan posyandu, baik posyandu balita maupun posbindu lansia. Dengan adanya pemeriksaan kesehatan setiap satu bulan sekali, tingkat kesehatan warga meningkat. Warga dapat

\section{c. Ekonomi}

Efek dari program Posdaya di bidang ekonomi adalah adanya peningkatan pendapatan masyarakat setelah adanya program. Pendapatan warga RW 02 setelah adanya Posdaya Bina Sejahtera mengalami memeriksakan kesehatan mereka dengan biaya yang murah bahkan ada yang diberikan pengobatan secara cuma-cuma atau gratis. Dengan adanya $\mathrm{BKB}$, posyandu balita dan posyandu lansia terjadi penurunan jumlah orang sakit. Jumlah orang yang mengikuti kegiatan BKB dan datang ke posyandu seiring berjalannya waktu setiap bulannya semakin bertambah. Pada Tabel 8 terlihat bahwa warga RW 02 yang mengikuti kegiatan BKB semakin meningkat. Jumlah warga yang mengikuti kegiatan pada bulan Februari 2009 BKB sebanyak 19 orang, dan jumlah tersebut terus meningkat sampai pada bulan Juli 2009 peserta yang mengikuti kegiatan BKB berjumlah 28 orang, meskipun terjadi penurunan di bulan Mei 2009 dikarenakan warga RW 02 sibuk mempersiapkan pemilihan umum (Pemilu) legislatif. Peserta BKB adalah para ibu yang baru menikah, mempunyai anak balita, atau ibu yang sedang dalam masa mengandung dan menyusui.

Jumlah Peserta posyandu balita Melati dan posbindu lansia Bina Sehat mengalami peningkatan. Pada bulan Februari 2009 peserta yang mengikuti posyandu balita Melati sebanyak 49 orang dan terus meningkat setiap bulannya. Rata-rata dalam setiap bulan sekali posyandu Melati melayani 50 -an orang balita dan ibu hamil. Hal tersebut juga terjadi pada posbindu lansia Bina Sehat, pada bulan Februari 2009 peserta yang mengikuti posbindu lansia Bina Sehat berjumlah 38 orang dan terus meningkat hingga dalam bulan Juli mencapai 48 orang. Rata-rata dalam setiap bulan sekali posbindu Lansia Bina Sehat melayani 40-an orang lansia. Peserta posbindu lansia kebanyakan warga masyarakat yang berumur 45 tahun ke atas.

peningkatan walaupun belum terlalu signifikan. LKM-P membuat kebutuhan modal pinjaman untuk usaha terbantu walaupun jumlahnya tidak terlalu besar.

Keberadaan LKM-P dapat menimbulkan semangat warga berwirausaha untuk menambah penghasilan warga RW 02 . Usaha yang sudah berjalan antara lain kripik 
singkong, rempeyek, jamur tiram, makanan ringan, jus jambu biji merah, telur asin, kikil dan pengrajin sepatu dan sandal. Tingginya angka keluarga miskin (Gakin) dan angka pengangguran setelah adanya LKM-P diharapkan akan menurun dan pada akhirnya pendapatan warga RW 02 dapat meningkat. Pada tahun 2008 dari 50 responden, jumlah orang mempunyai penghasilan kurang dari Rp 20.000,- sebanyak 12 orang (24 persen), kemudian jumlah orang yang berpenghasilan Rp 20.000,- sampai dengan Rp 50.000,sebanyak 6 orang (12 persen), sedangkan jumlah orang yang berpenghasilan tidak pasti sebanyak 10 orang (20 persen) dan jumlah orang yang berpenghasilan paling tinggi yaitu di atas Rp 100.000,- sebanyak 4 orang (8 persen). Setahun kemudian setelah Posdaya Bina Sejahtera telah berjalan dan usaha warga mulai berkembang, pada tahun 2009 jumlah orang mempunyai penghasilan kurang dari Rp 20.000,- dibandingkan tahun 2008 menurun menjadi 8 orang (16 persen), kemudian jumlah orang yang berpenghasilan Rp 20.000,- sampai dengan Rp 50.000,meningkat sebanyak 7 orang (14 persen), sedangkan jumlah orang yang berpenghasilan tidak pasti mengalami penurunan sebanyak 8 orang (16 persen) dan jumlah orang yang berpenghasilan paling tinggi yaitu di atas Rp 100.000,- bertambah sebanyak 6 orang (12 persen). Secara keseluruhan dapat disimpulkan bahwa setelah adanya peminjaman modal usaha melalui LKM-P pendapatan warga meningkat, walaupun peningkatan tersebut juga dapat dipengaruhi ada faktor lainnya seperti kenaikan gaji di tempat bekerja, bantuan dari program pemerintah maupun mendapatkan tambahan pendapatan dari kiriman anggota keluarga lainnya.

\section{Dampak Program}

Menurut Kunarjo (2002), dampak atau Impact dalam arti yang sederhana merupakan manfaat yang paling akhir. Selama pelaksanaan program Posdaya Bina Sejahtera sejauh ini berdampak positif bagi warga. Dampak yang dirasakan oleh warga setelah adanya program Posdaya Bina Sejahtera adalah mulai meningkatnya kesejahteraan masyarakat dan juga mulai terlihatnya kemandirian warga RW 02 . Hal ini ditunjukkan dengan menurunnya angka keluarga miskin (Gakin) dan turunnya angka penerima beras Raskin dan BLT.

Kesejahteraan dapat diartikan sebagai kondisi sejahtera dari suatu masyarakat dengan meningkatnya kesehatan, keadaan ekonomi dan kualitas hidup. Salah indikator keberhasilan dari pelaksanaan program Posdaya adalah meningkatnya kesejahteraan masyarakat. Tingkat kesejahteraan warga RW 02 dapat dilihat dari kemudahan akses dalam pendidikan, kesehatan dan keadaan ekonomi yang meningkat setelah pelaksaanaan Posdaya Bina Sejahtera. Tingkat Kesejahteran warga RW 02 meningkat setelah adanya program Posdaya juga terlihat dari menurunnya angka keluarga miskin (Gakin) dan turunnya angka penerima beras miskin (Raskin) dan BLT. Pada tahun 2008 jumlah keluarga miskin (Gakin) sebanyak 71 orang, sedangkan pada tahun 2009 setelah berjalannya Posdaya Bina Sejahtera selama setahun angka jumlah keluarga miskin (Gakin) mengalami penurunan sebanyak 8 orang dari 71 orang menjadi 63 orang.

Selain mengalami penurunan angka jumlah keluarga miskin (Gakin), terjadi juga penurunan angka penerima beras miskin (Raskin) dan BLT. jumlah penerima BLT dan Raskin sebanyak 65 orang dan 90 orang, sedangkan pada tahun 2009 menurun menjadi 57 orang dan 73 orang. Dengan demikian menurunnya angka penerima beras miskin (Raskin) dan BLT dapat dikatakan setelah adanya Posdaya tingkat kesejahteraan Posdaya meningkat.

Selain meningkatnya kesejahteraan, kemandirian warga RW 02 mulai terlihat. Kemandirian merupakan sesuatu yang perlu atau harus dimiliki oleh setiap individu oleh setiap individu sebagai sumberdaya manusia (Nawawi dan Martini, 1994). Karakteristik manusia yang berkualitas kepribadian mandiri adalah individu yang memilki sifat dan sikap rajin, sanggup bekerja keras, 
tekun, gigih, berdisiplin, berani merebut kesempatan, jujur, mampu bersaing, mampu bekerjasama, dapat dipercaya dan mempercayai orang lain, mempunyai citacita dan tahu apa yang harus dilakukan untuk mewujudkannya, terbuka terhadap kritik dan saran-saran, tidak putus asa. Hal itu berarti, seseorang yang memiliki kepribadian mandiri dalam menjalani kehidupan dan memperoleh penghasilan tidak tergantung pada bantuan pihak lain, misalnya berupa sumbangan, petunjuk, perintah, anjuran atau himbauan, tetapi individu yang mandiri lebih bersandar pada kemampuan diri sendiri. Keberadaan pihak lain lebih ditempatkan sebagai mitra kerja (kolega) yang saling menguntungkan.

Hasil pengamatan yang dilakukan di lapangan terhadap Posdaya Bina Sejahtera menunjukan bahwa kemandirian warga RW 02 termasuk kategori cukup tinggi. Dengan dana yang minim dan seadanya, tidak membuat pengurus dan kader patah semangat untuk mengembangkan Posdaya Bina Sejahtera. Hal ini tidak terlepas dari tingginya tingkat aspirasi, kreativitas, wawasan ke depan, dan semangat kerjasama, dan memiliki tingkat keuletan tinggi. Dengan adanya kemandirian diharapkan akan semakin menurunkan angka kemiskinan di masa yang akan datang.

Program Posdaya Bina Sejahtera berdampak positif bagi warga RW 02 yakni dapat meningkatkan tingkat kesejahteraan dan kemandirian masyarakat diharapkan akan adanya keberlanjutan di masa yang akan datang. Oleh karena itu, diperlukan kerjasama yang baik dari semua pihak yang terkait, baik Yayasan Damandiri, P2SDM IPB, pengurus dan kader Posdaya, warga RW 02 serta pihak Kelurahan Pasir Mulya dan Pemerintah Kota Bogor. Yayasan Damandiri dan P2SDM berperan untuk mendampingi, memberi masukan dan melakukan kontrol terhadap arah dari kegiatan Posdaya. Pengurus dan kader Posdaya serta warga RW 02 sebagai pelaksana program harus lebih bersemangat lagi untuk melaksanakan kegiatan dan mulai menyiapkan kader maupun motivator yang dapat mengerakkan untuk keberlanjutan Posdaya Bina Sejahtera di masa yang akan datang. Pihak Kelurahan Pasir Mulya dan Pemerintah Kota Bogor berperan untuk memfasilitasi masalah perijinan dan pendanaan kegiatan. Pemerintah Kota Bogor sebaiknya menyiapkan anggaran khusus berupa modal usaha dan dana pembiyaan kegiatan untuk membantu Posdaya Bina Sejahtera yang sangat potensial untuk dapat dikembangkan lagi.

\section{Kesimpulan}

Pelaksanaan program pemberdayaan Posdaya Bina Sejahtera dapat memberdayakan masyarakat dan sudah berjalan dengan baik. Mereka sangat terbantu dengan adanya Posdaya dan sebagian kegiatan Posdaya telah berhasil dan terus berlanjut sampai sekarang. Kemajuan yang paling dirasakan manfaatnya oleh masyarakat adalah dalam kegiatan bidang pendidikan dan kegiatan bidang kesehatan.

Faktor-faktor yang mempengaruhi pelaksanaan program Posdaya yakni faktor pendukung dan faktor penghambat. Penulis mengidentifikasi faktor yang mendukung pelaksanaan program yaitu : (1) Gotong royong masyarakat masih tinggi, (2) Rasa kebersamaan yang kuat, (3) Lamanya tinggal, (4) Kesiapan SDM untuk melaksanakan program Posdaya, (5) Mempunyai lahan kosong walaupun tidak banyak, dan (6) Sarana dan prasarana yang sudah ada walaupun tidak sepenuhnya memadai. Sedangkan faktor-faktor yang menghambat pelaksanaan program yaitu : (1) Belum adanya binaan khusus dari instansi, (2) Sebagian masyarakat belum semuanya mengetahui adanya Posdaya, dan (3) Keterbatasan waktu. Warga RW 02 menyambut positif adanya Posdaya Bina Sejahtera, terlihat dari antusiasme warga dalam berpartisipasi pada kegiatan Posdaya Bina Sejahtera. Partisipasi warga dari mulai tahap perencanaan, tahap pelaksanaan, tahap menikmati hasil dan tahap evaluasi tergolong cukup tinggi. 
Output program dapat terlihat pada perubahan pengetahuan, perubahan sikap dan perubahan perilaku. Ketiga perubahan tersebut dirasakan oleh warga RW 02 setelah adanya Posdaya Bina Sejahtera. Efek program Posdaya merupakan hasil dari pelaksanaan program di bidang pendidikan, kesehatan dan ekonomi. Posdaya Bina Sejahtera mempunyai efek yang baik bagi warga RW 02 hal terlihat dari peningkatan kemudahan akses terhadap pendidikan, akses terhadap kesehatan dan peningkatan tingkat kesehatan masyarakat, dan peningkatan pendapatan masyarakat setelah adanya program LKM-P dan usahatani ramah lingkungan. Dampak merupakan manfaat yang paling akhir dari pelaksanaan program Posdaya. Selama pelaksanaan program Posdaya Bina Sejahtera sejauh ini berdampak positif bagi warga. Hal ini ditunjukkan dengan mulai meningkatnya kesejahteraan masyarakat dan juga mulai terlihatnya kemandirian warga RW 02.

Program Posdaya Bina Sejahtera diharapkan akan berlanjut di masa yang akan datang. Oleh karena itu, diperlukan kerjasama yang baik dari semua pihak yang terkait, baik Yayasan Damandiri, P2SDM IPB, pengurus dan kader Posdaya, warga RW 02 serta pihak Kelurahan Pasir Mulya dan Pemerintah Kota Bogor karena Posdaya Bina Sejahtera potensial untuk dapat dikembangkan lagi.

\section{Daftar Pustaka}

Agusta, Ivanovich. 2000. Evaluasi Program Pengembangan Kecamatan. Jakarta. Bappenas.

Badan Pusat Statistik. Angka Kemiskinan Indonesia tahun 2007. http://www.detik.com. Diakses tanggal 14 Mei 2009, 05.30.

Febriana, Yohana Desi. 2008. Partisipasi Masyarakat dalam Program Corporate Social Responsibility
"Kampung Siaga Indosat" (Kasus: RW 04, Keluarahan Manggarai, Kecamatan Tebet, Jakarta Selatan). Skripsi. Program Studi Komunikasi dan Pengembangan Masyarakat. Fakultas Pertanian. Bogor: Institut Pertanian Bogor.

Kunarjo. 2002. Perencanaan dan Pengendalian Program Pembangunan. Jakarta: UI Press.

Murray, Ross dan B.W. Lappin. 1967. Community Organization Theory, Principles and Practice, 2nded. New York: Harper and Row Publisher.

Singarimbun, M. dan S. Effendi. 1989. Metode Penelitian Survai. Jakarta: LP3ES.

Sitorus, MT Felix.1998. Penelitian Kualitatif Suatu Pengantar. Bogor: Kelompok Dokumentasi Ilmu Sosial.

Stake, R.E. 1995. The Art of Case Study Research. London: SAGE.

Suyono, H dan R. Haryanto. 2009. Buku Pedoman Pembentukan dan Pengembangan Pos Pemberdayaan Keluarga. Jakarta: PT Balai Pustaka.

Yin, Robert K. 2002. Studi Kasus (Design dan Metode), Edisi Revisi. Jakarta: PT Raja Grafindo Persada. 